\title{
SLOWING THE FLOW IN PICKERING: QUANTIFYING THE EFFECT OF CATCHMENT WOODLAND PLANTING ON FLOODING USING THE SOIL CONSERVATION SERVICE CURVE NUMBER METHOD
}

\author{
H. THOMAS \& T.R. NISBET \\ Centre for Ecosystems, Society \& Biosecurity, Forest Research, UK.
}

\begin{abstract}
The Soil Conservation Service (SCS) Runoff Curve Number method has been successfully applied to the Pickering Beck catchment at Pickering in North Yorkshire to assess the impact of land use change on flood flows. While limited-scale woodland creation (3\% of the catchment) was predicted to have a small effect on the range of peak flows studied ( $<1 \%$ to $4 \%$ reduction), in line with previous model applications in the catchment, the conversion of the $25 \%$ cover of existing woodland to improved grassland produced a large increase in peak flow, up to $41 \%$ for a 1 in 100-year event. These numbers need to be treated with particular caution since the SCS method remains to be validated for UK conditions, however, they support growing evidence that woodland creation and management could have a significant role to play in flood risk management. The SCS method provides a potentially powerful tool for evaluating the impact of land-use change and management on flood runoff, as well as for identifying areas where such measures could be most effective.

Keywords: curve number method, flooding, land-use change, natural flood management, rainfall-runoff modelling.
\end{abstract}

\section{INTRODUCTION}

Recent flooding incidents in the UK have put immense pressure on existing flood defences, and have strengthened the case for the implementation of Natural Flood Management (NFM) measures in catchments to complement and reduce the strain on these hard-engineered forms of protection.

To develop a better understanding of how flood flows are generated across catchments and where NFM measures, in particular woodland planting, would be most effective, a hydrological assessment has been undertaken using the Soil Conservation Service Runoff Curve Number (SCS CN) methodology reported in Urban Hydrology for Small Watersheds TR-55 [1]. This method was originally developed to facilitate the hydrological assessment of catchments in North America subject to land use change, principally urbanisation.

The principles of the approach were adapted to quantify the effects of woodland planting measures in the Pickering Beck catchment in North Yorkshire, UK, as part of the "Slowing the Flow at Pickering" project [2]. A spatial application using a Geographical Information System (GIS) was used to identify key areas of runoff generation within the catchment. This offers a useful tool to help target woodland planting to where it can be most effective at alleviating downstream flood risk. 


\section{MATERIALS AND METHODS}

2.1 Study area and the slowing the flow at pickering project

The 'Slowing the Flow at Pickering' project was established in April 2009 to look at how changes in land use and land management can help to reduce flood risk in the town of Pickering in North Yorkshire. Pickering has a long history of flooding, with four floods in the last fifteen years (1999, 2000, 2002 and 2007). The 2007 flood was the most serious to date, causing an estimated $£ 7$ million of damage to residential and commercial properties. Whilst a flood alleviation capital scheme had been proposed to alleviate the problem, a cost-benefit analysis showed this to be unaffordable when set against national cost-benefit thresholds and other priorities. The use of high flood walls was also not favoured by the local community due to aesthetic impacts on the town. The project represented a new approach to flood management that sought to work with natural processes to help reduce the risk of flooding for affected communities.

A crucial element of the project was to understand better how floods are generated in the catchment and how the way the land is used and managed affects the speed and volume of flood flows. The combined effects of past land management practices by humans over centuries are thought to have increased flood risk by promoting rapid runoff and increasing siltation within river channels, although more recent changes, for example afforestation since 1945, may have partly offset this trend. There are four principal land uses in the c. $68 \mathrm{~km}^{2}$ catchment of the Pickering Beck that drains to Pickering, comprising forest, arable, heather moorland and improved grassland. The overall aim of the project was to demonstrate how land-use change and improvements in management practices could help to restore the catchment's natural flood attenuation capacity.

\subsection{Data sources}

Land use/cover data were extracted from the LCM2000 Land Capability Map [3] dataset and merged with the Hydrology of Soil Types (HOST) dataset [4], which was then used to assign appropriate runoff curve numbers according to the SCS CN method (detailed in Section 2.3 below). A 1:50,000 Digital Elevation Model was used to delineate the catchment boundary for modelling purposes.

Rainfall and flow data were obtained from two Environment Agency gauges situated within the catchment whilst design rainfall events were generated using the Revitalised Flood Estimation Handbook ( $\mathrm{ReFH})$ methodology using appropriate catchment parameters.

\subsection{Soil conservation service runoff curve number model}

The SCS Curve Number model has been widely used internationally for water resources management and planning [5-9]. Halcrow [10] applied the SCS CN method within a UK context to establish baseline hydrological conditions in the Allan Water catchment in Scotland.

The model estimates precipitation excess as a function of cumulative precipitation, soil cover, land use, and antecedent moisture, using the following equation:

$$
Q=\frac{(P-I a)^{2}}{(P-I a)+S}
$$




\section{Flood Risk Management and Response}

Where

$\mathrm{Q} \quad=$ runoff

$\mathrm{P} \quad=$ rainfall

Ia $\quad=$ the initial abstraction (initial loss)

$\mathrm{S} \quad=$ potential maximum retention, a measure of the ability of a catchment to abstract and retain storm precipitation.

Initial abstraction (Ia) comprises all water losses before runoff begins. It includes water retained in surface depressions, water intercepted by vegetation, evaporation, and soil infiltration. Ia is highly variable but generally well correlated with soil and land cover parameters. Through studies of many small agricultural watersheds in North America, Ia was found to be approximated by the following empirical equation:

$$
I a=0.2 \mathrm{~S}
$$

$\mathrm{S}$ is related to the soil and land cover conditions of the catchment through the $\mathrm{CN}$. $\mathrm{CN}$ has a range of 0 to 100 , and $\mathrm{S}$ is related to $\mathrm{CN}$ by:

$$
S=\left(\frac{25400-254 C N}{C N}\right)(\text { SI units })
$$

$\mathrm{CN}$ values range from 100 (open water) to approximately 30 for permeable soils with high infiltration rates.

\subsection{Estimating curve number}

The $\mathrm{CN}$ for a catchment can be estimated as a function of soil type and land cover using tables published by the SCS in the United States Department of Agriculture, Urban Hydrology for Small Watersheds TR 55 (1986) report.

For a catchment that consists of several soil types and land uses, a composite $\mathrm{CN}$ is calculated as:

$$
C N_{\text {composite }}=\frac{\sum A i C N i}{\sum A i}
$$

In which $\mathrm{CNcomposite}=$ the composite $\mathrm{CN}$ used for runoff volume computations; $\mathrm{i}=$ an index of catchment subdivisions of uniform land use and soil type; $\mathrm{CNi}=$ the $\mathrm{CN}$ for subdivision $\mathrm{i}$; and $\mathrm{Ai}=$ the drainage area of subdivision $\mathrm{i}$.

The method classifies soils into one of four hydrologic soil groups (HSGs; A, B, C and D) based on their hydrological characteristics. This includes the infiltration rate (the rate at which water enters the soil at the surface) and the transmission rate (the rate at which water moves within/through the soil). Approximate numerical ranges for both rates were first published by Musgrave [11]. The four groups are defined as follows:

1. Group A (low runoff potential): soils with low runoff potential and high infiltration rates even when thoroughly wetted. High rates of water transmission (greater than $\sim 8 \mathrm{~mm} / \mathrm{h}$ ).

2. Group B: soils with moderate infiltration rates when thoroughly wetted. These soils have a moderate rate of water transmission $(\sim 4$ to $8 \mathrm{~mm} / \mathrm{h})$. 
Table 1: Conversion used for HOST soil classes to SCS soil classes.

\begin{tabular}{lll}
\hline $\begin{array}{l}\text { Standard Percentage } \\
\text { Runoff }(\text { HOST) }(\%)\end{array}$ & SCS Soil Class & HOST soil class \\
\hline$<10$ & A & $1,2,4,11,13$ \\
$10-20$ & B & 3,5 \\
$20-40$ & C & $6,9,10,14,16,17,18,24$ \\
$>40$ & D & $7,8,12,15,19,20,21,22,23,25,26,27,28,29$ \\
\hline
\end{tabular}

Table 2: Curve numbers assigned to land use and soil classes using the SCS land use descriptions and cross referencing these to UK land cover types present in the catchment.

\begin{tabular}{llcccc}
\hline LCM2000 Description & SCS Land Use Description & Soil A & Soil B & Soil C & Soil D \\
\hline Woodland & Fair, woods & 36 & 60 & 73 & 79 \\
Arable \& horticulture & Good, fallow ground & 74 & 83 & 88 & 90 \\
Grassland & Poor, pasture & 68 & 79 & 86 & 89 \\
Set-a-side grassland & Meadow & 30 & 58 & 71 & 78 \\
Bracken & Fair, brush & 35 & 56 & 70 & 77 \\
Dwarf shrub heath & Good, brush & 48 & 67 & 77 & 83 \\
Inland water & Open water & 100 & 100 & 100 & 100 \\
Bare ground & Fallow, bare soil & 77 & 86 & 91 & 94 \\
Suburban & Residential & 61 & 75 & 83 & 87 \\
Urban & Urban & 89 & 92 & 94 & 95 \\
\hline
\end{tabular}

3. Group C: soils with low infiltration rates when thoroughly wetted. These soils have a low rate of water transmission ( 1 to $4 \mathrm{~mm} / \mathrm{h})$.

4. Group D: soils with high runoff potential. They have very low infiltration rates when thoroughly. These soils have a very low rate of water transmission $(<1 \mathrm{~mm} / \mathrm{h})$.

The HSGs were converted to fit the UK's HOST classification system by Halcrow [10] based on Standard Percentage Runoff values, as shown in Table 1.

Curve numbers were assigned to different combinations of land use and soil classes using the SCS land use descriptions and cross referencing these to UK land cover types present in the catchment (Table 2). Different values are available for each land cover type depending on general condition, ranging from poor, fair to good. Numbers were selected based on local judgement. This allowed a SCS Curve Number grid to be generated for the catchment and for weighted average curve numbers to be determined for each sub-catchment represented in the model.

\subsection{Rainfall-runoff modelling using HEC-HMS and the SCS CN method}

The Hydrologic Modeling System (HEC-HMS) is designed to simulate the rainfall-runoff processes within catchments. It is applicable to diverse geographic areas for solving a wide range of problems, including managing flood flows draining small urban and headwater catchments to large river basins. 


\section{Flood Risk Management and Response}

HEC-HMS is a numerical model that can be used to simulate catchment and channel behaviour and thereby predict river flows and response times. It was applied in this study to run the SCS CN method to investigate the impact of land use change on flood runoff within the Pickering Beck catchment.

2.6 Calibration of the SCS CN method to the revitalised flood estimation (ReFH) method and measured June 2007 flood event

The SCS Runoff Curve Number method and HEC-HMS model were used to generate a set of predicted flood growth curves based on the existing mix of soil types and land covers in the catchment. The results are compared with the growth curve using the observed gauged flow data along with those derived from the FEH Revitalised Flood Hydrograph Method and FEH Pooling Group analysis in Fig. 1. This shows that the method provides a reasonable fit in the middle of the flow range but both under-predicts smaller flood events and over-predicts larger ones.

These discrepancies could be due to the following factors:

1. The $\mathrm{CN}$ values are derived from US studies and catchment conditions. While an attempt was made to translate values to UK soil and land cover types, as well as general management condition, this is based on judgement rather than calibrated values.

2. The use of the HOST data set and mapped Soil Associations to assign catchment soils to HSGs within the SCS model introduces significant uncertainties linked to the scale of mapping and soil variability. This could introduce marked local discontinuities in runoff conditions that are not reflected by the model.

Early development of the SCS CN method established that there could be significant variability in the curve number, and that the same catchment could have more than one curve number, or indeed, a set of curve numbers [12]. Ponce \& Hawkins [13] stated that the likely

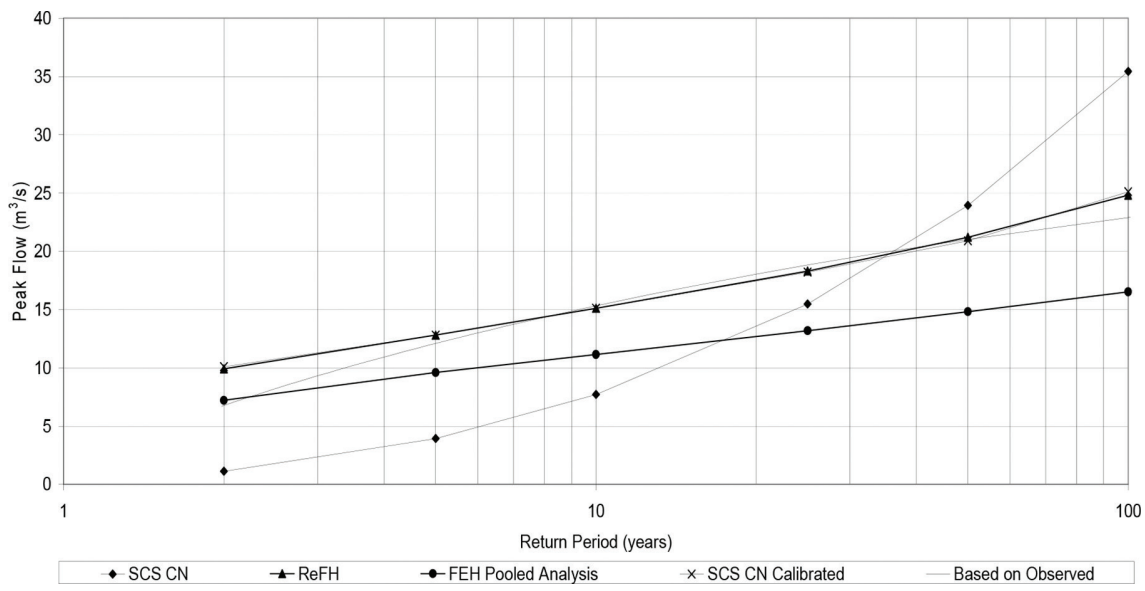

Figure 1: Comparison of the flood growth curves of the Pickering Beck catchment from five different analyses. 


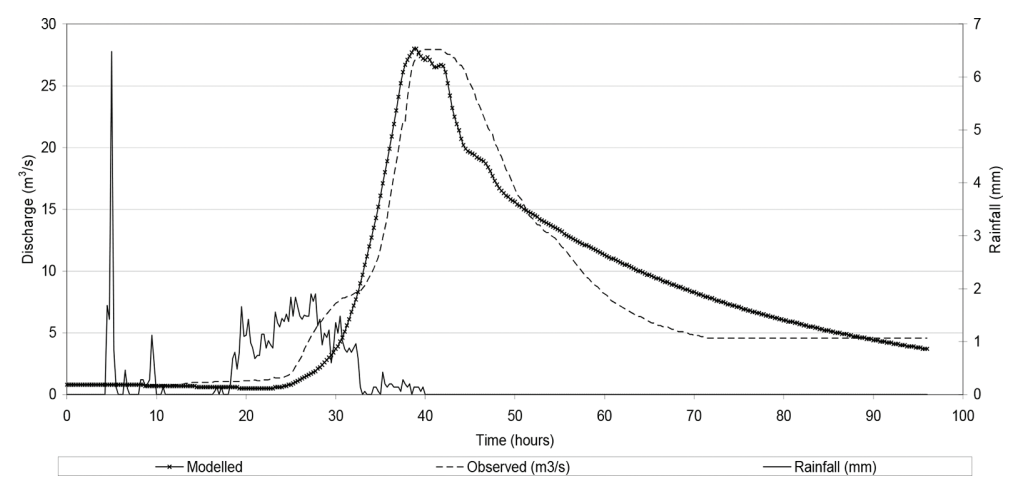

Figure 2: Modelled versus observed hydrograph for the June 2007 flood event at Pickering Beck gauging station.

sources of this variability are the spatial variability of storm and catchment properties, temporal variability of storm rainfall, i.e. storm intensity, and, differing antecedent rainfall and associated soil moisture conditions.

In order to address this variability and improve model fit, a calibration exercise was undertaken to scale the original $\mathrm{CN}$ values for each land cover and soil type combination so that the modelled peak flows better matched those of the ReFH growth curve. This involved applying a separate scaling factor for each return period until a satisfactory peak flow was achieved.

The adjusted CN values were applied to the June 2007 flood event, the highest recorded flow on record at the Pickering Beck gauging station, to compare the modelled versus observed hydrograph (Fig. 2) This gave an acceptable fit, with peak flows of 28 and $27.9 \mathrm{~m} 3 / \mathrm{s}$ and total hydrograph volumes of 2,177,603 and 2,253,960 $\mathrm{m}^{3}$ for predicted and observed conditions, respectively.

\section{RESULTS AND DISCUSSION}

\subsection{The effect of land use change on runoff generation}

The SCS CN methodology was applied to the Pickering Beck catchment to assess the effect of woodland planting measures in the catchment. The following scenarios were applied:

1. Baseline land use scenario using the existing land cover map, showing $16.2 \mathrm{~km}^{2}$ of woodland in the catchment

2. An additional $7 \mathrm{~km}^{2}$ of woodland planting in the catchment, assuming all previously mapped opportunities were achievable.

3. An additional $0.2 \mathrm{~km}^{2}$ of woodland representing that achieved in the catchment since the Slowing the Flow project commenced in 2009.

4. Conversion of all existing woodland $\left(16.2 \mathrm{~km}^{2}\right)$ to improved grassland

4. Conversion of all existing woodland to Dwarf Shrub Heath.

The FEH was used to generate design 24-hour rainfall events for given return periods as shown in Table 3. 


\section{Flood Risk Management and Response}

Figure 4 shows the effect of the two woodland planting scenarios on peak flows for the range of return periods. The results for Scenario 2 (opportunity mapping) predicted a $14 \%$ decrease in peak flow for more frequent events (e.g. 1 in 2 year) and a $6 \%$ decrease for the less frequent 1 in 100-year flood. The small areas of woodland planted under Scenario 3 produced a $4 \%$ decrease for predicted peak flows to 1 in 25 years and a $<1 \%$ decrease for larger events. These numbers are relatively similar to those generated by a separate modelling study by Odoni and Lane [14] using a different, combined hydrology-hydraulic model (OVERFLOW).

Existing improved grassland amounts to $\sim 12 \mathrm{~km}^{2}$ of the catchment (18\%), while dwarf shrub heath covers $\sim 3.4 \mathrm{~km}^{2}(5 \%)$. Scenarios 4 and 5 involved converting all $16.2 \mathrm{~km}^{2}(\sim 25 \%)$ of existing woodland to each of these land covers.

As expected, converting all woodland in the catchment to improved grassland would have a much larger effect on peak flows, increasing more frequent floods by as much as $87 \%$ (1 in 2 year flood) and up to $41 \%$ for less frequent events ( 1 in 100 year). Conversion of woodland to dwarf shrub heath had a smaller effect, increasing peak flows for a 1 in 2-year flood by $27 \%$ and by $14 \%$ for a 1 in 100-year event. These represent large reductions and are above or at the top end of ranges reported by other UK modelling studies based on the scale of land cover change involved [15]. In view of the scaling required for the calibration exercise and the fact that the method remains to be validated under UK conditions, these results need to be treated with caution. However, they do add further support to the growing evidence that woodland creation and management could have a significant role to play in flood risk management.

Table 3: FEH-generated design 24-hour rainfall events.

\begin{tabular}{lc}
\hline Return period & Rainfall depth $(\mathrm{mm})$ \\
\hline 2 & 30.2 \\
5 & 38.7 \\
10 & 45.7 \\
25 & 56.3 \\
50 & 65.7 \\
100 & 76.5 \\
\hline
\end{tabular}

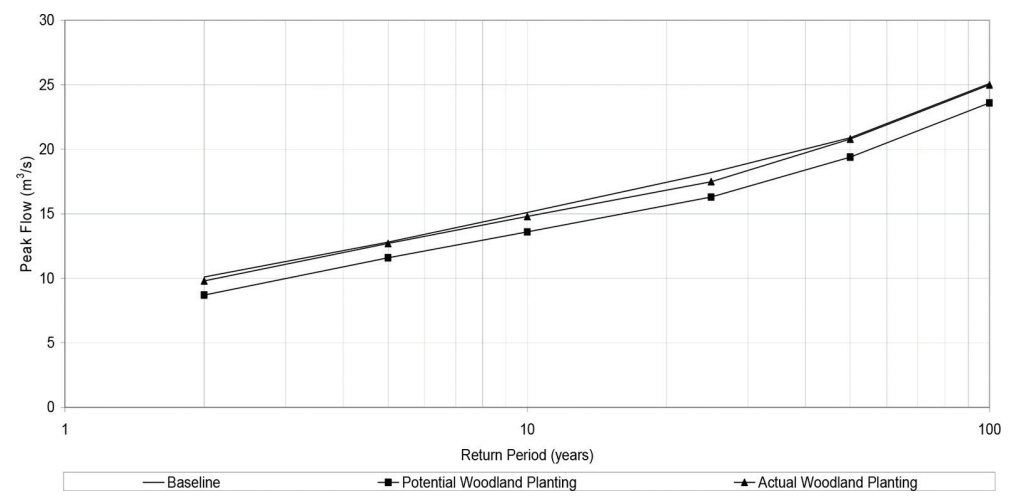

Figure 3: Effect of woodland planting on peak flows. 


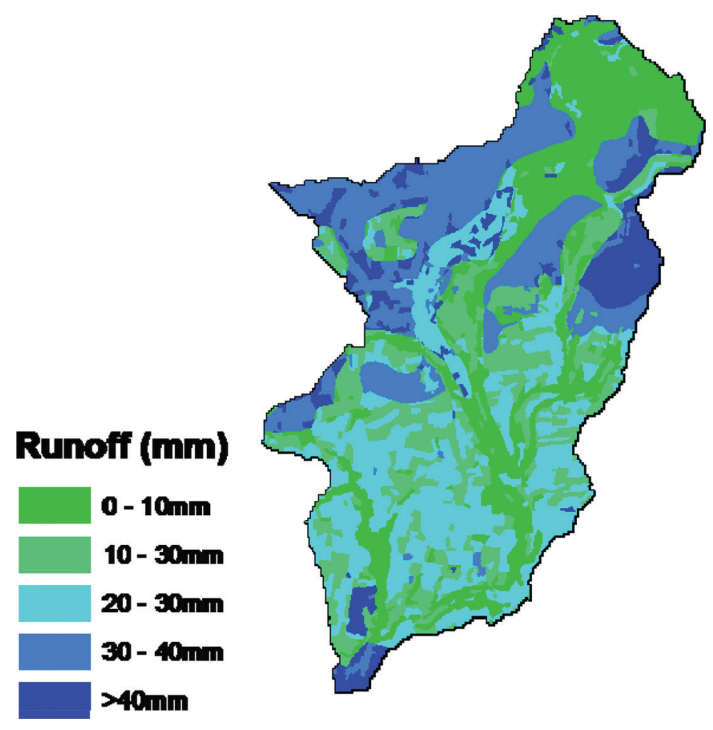

Figure 4: Runoff from June 2007 rainfall event (total rainfall $85.5 \mathrm{~mm}$ ).

\subsection{Spatial representation of the SCS CN method}

The SCS CN method can be used to identify areas within catchments that generate the greatest volumes of runoff. This could provide a very useful tool for targeting NFM measures, such as woodland planting, to where they would be most effective, as well as allow different options to be quantified and compared.

As an example, Fig. 4 shows the spatial distribution of runoff within the Pickering Beck catchment for the June 2007 rainfall event, based on the modelled runoff from each $50 \mathrm{~m}$ by $50 \mathrm{~m}$ grid cell. The greatest runoff ( $>40 \mathrm{~mm}$ in some areas) for this $85.5 \mathrm{~mm}$ storm event occurred on areas predominantly covered with improved grassland and heath in the northeast of the catchment, but also from existing woodland in the northwest (as well as built up areas to the south).

\section{CONCLUSIONS}

The Soil Conservation Service (SCS) Runoff Curve Number method has been successfully applied to the Pickering Beck catchment at Pickering in North Yorkshire to assess the impact of land use change on flood flows. While limited-scale woodland creation (3\% of the catchment) was predicted to have a small effect on the range of peak flows studied $(<1 \%$ to $4 \%$ reduction), in line with previous model applications in the catchment, the conversion of the $25 \%$ cover of existing woodland to improved grassland produced a large increase in peak flow, up to $41 \%$ for a 1 in 100 year event. These numbers need to be treated with particular caution since the SCS method remains to be validated for UK conditions, however, they support growing evidence that woodland creation and management could have a significant role to play in flood risk management. The SCS method provides a potentially powerful tool for evaluating the impact of land use change and management on flood runoff, as well as for identifying areas where such measures could be most effective. 
20 Flood Risk Management and Response

\section{REFERENCES}

[1] United States Department of Agriculture Urban hydrology for small watersheds, Technical Release 55 (TR-55), 2nd edn., Natural Resources Conservation Service, Conservation Engineering Division, 1986.

[2] Nisbet, T.R., Roe, P., Marrington, S., Thomas, H., Broadmeadow, S. \& Valatin, G., Slowing the flow at pickering, final report phase II for the department of environment, food and rural affairs (Defra), Project RMP5455, Defra, London, 2015.

[3] Fuller, R.M., Smith, G.M., Sanderson, J.M., Hill, R.A., Thomson, A.G., Cox, R., Brown, N.J., Clarke, R.T., Rothery, P. \& Gerard, F.F., Countryside Survey 2000 Module 7 LAND COVER MAP 2000 FINAL REPORT CSLCM/Final, Centre for Ecology and Hydrology, 2002.

[4] Boorman, D.B., Hollis, J.M. \& Lilly, A., Hydrology of soil types: a hydrologically based classification of the soils of the United Kingdom, Institute of Hydrology Report No.126, Institute of Hydrology, Wallingford, 1995, available at http://www.ceh.ac.uk/ products/publications/documents/IH126HYDROLOGYOFSOILTYPES.pdf

[5] Hawkins, R.H., Runoff curve numbers with varying site moisture. Journal of the Irrigation and Drainage Division, ASCE, 10(4), pp. 389-398, 1978.

[6] Ragan, R.M. \& Jackson, T.J., Runoff synthesis using Landsat and SCS model. Journal of Hydrologics Division, ASCE, 106, pp. 667-678, 1980. http://dx.doi.org/10.1111/j.1752-1688.1980.tb02504.x

[7] Slack, R.B. \& Welch, R., Soil conservations service runoff curve number estimates from Landsat data. Water Resources Bulletin, 16(5), pp. 887-893, 1980.

[8] Hawkins, R.H., Asymptotic determinations of runoff curve numbers from data. Journal of Irrigation and Drainage Engineering, 119, pp. 334-345, 1993. http://dx.doi.org/10.1061/(ASCE)0733-9437(1993)119:2(334)

[9] Lewis, M.J., Singer, M.J. \& Tate, K.W., Applicability of SCS curve number method for a California Oak Woodlands watershed. Journal of Soil Water Conservation, 55(2), pp. 226-230, 2000.

[10] Halcrow, Allan water natural flood management techniques and scoping study, Report to Scottish environment agency, 2011.

[11] Musgrave, G.W., How much of the rain enters the soil? Water Yearbook of Agriculture, U.S. Department of Agriculture: Washington, DC. pp. 151-159, 1955.

[12] Hjelmfelt, A.T., Investigation of curve number procedure. Journal of Hydraulic Engineering. ASCE, 117(6), pp. 725-737, 1991. http://dx.doi.org/10.1061/(ASCE)0733-9429(1991)117:6(725)

[13] Ponce, V.M. \& Hawkins, R.H., Runoff curve number: has it reached maturity? Journal of Hydrologic Engineering, 1, pp. 11-19, 1996. http://dx.doi.org/10.1061/(ASCE)1084-0699(1996)1:1(11)

[14] Odoni, N.A. \& Lane, S.N., Assessment of the impact of upstream land management measures on flood flows in Pickering Beck using Overflow. Forestry Commission, [Online], 2010, available at http://www.forestry.gov.uk/pdf/Pickering_crim_report_ April_2010.pdf/\$FILE/Pickering_crim_report_April_2010.pdf

[15] McIntyre, N.L. \& Thorne, C.R. (eds), Land use management effects on flood flows and sediments - guidance on prediction CIRIA report C719 construction industry research and information association, London, 2013. 